\title{
Interference Error Analysis in EFL Class
}

\author{
Tsovinar Arakelyan \\ Police Educational Complex
}

\begin{abstract}
The present article aims at investigating the nature of interference errors in EFL class. Based on a case study, it analyzes the Armenian speakers' interference errors in EFL class. In order to give a vivid picture of their nature, these errors have been categorised according to the model of Hierarchy of Difficulty propelled by Stockwell and Prator. The beneficial outcomes of the study may be implemented in further pedagogical research towards finding an optimal model of interference errors correction.
\end{abstract}

Key words: overgeneralization, transitional competence, cross-linguistic influence, interlanguage, input, uptake.

\section{Introduction}

Learning a foreign language is not an easy undertaking. One's personality is affected when he/she makes efforts to go beyond the confines of his/her first language and gets involved in a new language with new culture, new ways of thinking, feeling and acting. Thus, as Brown states, a combination of total commitment and involvement, as well as total physical, intellectual and emotional responses are necessary to send and receive messages in a foreign language. This transitional path of passing from the native language system to the foreign language system and language building process are mostly subject to cross-linguistic influence (CLI) (Brown 2007:208). Specifically, CLI suggests that prior experience plays a crucial role in any learning act and the influence of the native language as prior experience must not be overlooked. It means that in the early stages of foreign language learning, when its system is unfamiliar to the learner, the native language is the only linguistic system upon which the learner can draw. In turn, this interlingual influence gives birth to a specific language system called interlanguage, typical to any individual. The advent of interlanguage presupposes a flaw of errors onto the language building process. As a matter of fact, in order to lead the learner to the attainment of appropriate language capacities, these errors need specific treatment.

\section{Interference and Overgeneralization}

Human beings approach any new problem with the help of an established set of cognitive structures and through these prior experiences they attempt a solution. The same mechanism functions in the second language acquisition process, when the learner 
gradually approximates the target language and passes through the stages of language building based on the prior linguistic data of his native language. Thus this approximation process generates a specific language system called "interlanguage". The term "interlanguage" was introduced by the American linguist Larry Selinker to refer to the second language adult learners' grammatical system. He described interlanguage as a separate linguistic system based on the observable output which results from a learner's attempted production of a target language (Selinker 1972:214). Interlanguage refers to the separateness of a second language learner's system, a system that has a structurally intermediate status between the native and the target languages. Equally important, as any learner tries to form his own self-contained linguistic system, interlanguage is peculiar to that individual alone (Corner 1971:151). This is neither the system of the native language nor the system of the target language, but a system based upon the best attempt of the learner to bring order and structure to the linguistic stimuli surrounding them (Brown 2007:256). Thus the concept of interlanguage might be better understood if it is thought of as a continuum between L1 and L2 along which all learners traverse. At any point along the continuum, the learners' language is systematic, rule-governed and common to all learners, any difference being explicable by differences in their learning experiences (Larsen-Freeman 1991:60).

Along with interference, overgeneralization is a crucially important strategy in human learning. To generalize means to infer or derive a law, rule, or conclusion from the observation of particular instances. Much of human learning involves generalization. The learning of concepts in early childhood is a process of generalizing. A child who has been exposed to various kinds of animals gradually acquires a generalized concept of "animal". That same child, however, at an early stage of generalization, might see a horse for the first time and, having been familiar with dogs, might overgeneralize the concept of "dog" and, calling the horse a dog. Similarly, a number of animals might be placed into a category of "dog" until the general attributes of a larger category of "animals" have been learned. As for the second language acquisition, it has been common to refer to overgeneralization as a process that occurs when the second language learner acts within the target language, generalizing a particular rule or item in the second language, irrespective of the native language, beyond legitimate bounds. For instance, it is common among learners of English as a foreign language to overgeneralize regular past tense endings (worked, finished) as applicable to all past tense forms (goed, speaked) until they recognize a subset of verbs that belong to an irregular category. This fact implies that the learners are prone to overgeneralize the rules within a target language before gaining some exposure and familiarity with it. Such overgeneralization is committed by learners of English from almost any native language background.

To sum up, interference and overgeneralization strongly correlate with each other as interdependent learning strategies. Interference of the first language in the second one is 
simply a form of generalization that takes prior first language experiences and applies them incorrectly. Overgeneralization is the incorrect application of previously learned second language material to a current second language context. All generalization involves transfer, and all transfer involves generalization.

\section{Interference Error Analysis}

Learning is fundamentally a process that involves the making of mistakes. Mistakes, misjudgments and erroneous assumptions form an important aspect of learning any skill or acquiring any information. For instance, you learn to swim by first jumping into the water and moving your arms and legs, and then you understand that there is a certain combination of movements that enables you to keep balance on water and swim. The first mistakes of learning to swim are giant ones but they gradually diminish, as you learn from those mistakes. Learning to swim, to play tennis, to type or to read all involve a process in which success comes by profiting from mistakes and by using mistakes to obtain corrective feedback (Brown 2007:217).

Language learning, in this sense, is like any other learning. Unquestionably, children make countless mistakes in the first language acquisition process. Most of these mistakes are logical in the limited linguistic system within which children operate and, by carefully processing feedback from others, they slowly but surely learn to produce what is acceptable speech in their native language. Similarly, second language learning involves the process of trial-and-error, typical of first language acquisition. Inevitably, learners make mistakes in the process of acquisition and that process will be impeded if they do not commit errors and then benefit from various forms of corrective feedback (Brown 2007:257). Errors, as manifestations of learning process, arise from different sources: interlingual errors of interference from the native language, intralingual errors within the target language, the sociolinguistic context of communication, psycholinguistic or cognitive strategies and, no doubt, countless affective variables. As Corder noted: “A learner's errors ... are significant in [that] they provide how language is learned or acquired, what strategies or procedures the learner is employing in the discovery of the language" (Corder 1967:167).

In this research we will look more closely at the nature of interlingual errors of interference from the native language and will try to classify them into definite categories. In fact, having examined the nature of the Armenian students' mistakes in EFL class, we have come to the conclusion that they can be grouped into definite categories according to some common features. Thus, we tried to fit these categories into the model of Hierarchy of Difficulty propelled by Stockwell and Prator. Actually, it presents a five-level model that can be applied to any two languages and make it possible to predict second language learners' difficulties in any language with a fair degree of certainty and objectivity (Prator 1967). The first or "zero" degree of difficulty presents complete one-to-one correspondence and transfer, while the fifth degree of 
difficulty was the height of interference. Most importantly, this model of Hierarchy of Difficulty is applicable to both grammatical and phonological features of language. The six categories are listed below in ascending order of difficulty. All the examples are taken from the Armenian adult speakers' mistakes made in a classroom context. Precisely some common interference errors made by the students of the first, second and third years of bachelor' s degree in law are analyzed.

Level 0 - Transfer. No difference or contrast is present between the two languages. The learner can simply transfer positively a sound, structure or lexical item from the native language to the target language. Examples: In the following statement "I am eighteen years old" the Armenian students face no difficulty with the appropriate choice of the verb "to be" as it takes the same form in Armenian as well: "bu unuuGintp unuptцuG $t u »$. Here we deal with positive interlingual transfer. In contrast, Armenian students studying French face negative transfer as the same statement is expressed in French with the verb "to have"-J'ai dix-huit ans.

Level 1 - Coalescence. Two items in the native language become coalesced into essentially one item in the target language and vice versa. This requires that learners overlook a distinction they have been accustomed to. For example, in English thirdperson possessives require gender distinction (his/her), while in Armenian they do not. An Armenian speaker learning English may overlook the distinction between listen and hear, besides and except, few and little, many and much, as and like, since they have the same form in Armenian. The choice between the use of the present indefinite or the present continuous is also an example of coalescence as there is a single tense of the verb in Armenian which is used to express present action with no distinction whether the action is taking place at the moment of speech or in the present context in general.

Level 2 - Underdifferentiation. An item in the native language is absent in the target language. For example, the possessive case in English is formed by adding's to the stem of the animate object. Meanwhile, the equivalent case in Armenian does not require any distinction between animate and inanimate nouns. Thus, Armenian speakers tend to overgeneralize the use of the possessive case and mistakenly use the classroom 's windows.

Level 3 - Reinterpretation. An item that exists in the native language is given a new shape or distribution in the target language. For example, the sounds $[j],[\mathrm{t}]]$ and $[f]$ correspond to a single letter in Armenian, but in English they are written by means of the combination of two letters $s h, c h, p h$. Furthermore, the pronunciation of the letters $g$ and $c$ differs in English according to their placement before $e, i, y$. Meanwhile, in Armenian they are pronounced in the same way regardless of their position. As a result, the Armenian learners must adopt a new cognitive strategy to distinguish the sounds according to their given position. The failure in this differentiation process gives free way to a flaw of pronunciation mistakes. 
Level 4 - Overdifferentiation. A new item, bearing little if any similarity to the native language item, must be learned. For example, the Armenian learner must learn to omit the definite article before nouns speaking about things and people in general which is just the contrary in Armenian. In the statement "Burglary is a common crime in developing countries" the Armenian students mistakenly use "the burglary" as a result of negative interlingual transfer.

Level 5 - Split. One item in the native language takes multiple forms in the target language, requiring the learner to make a new distinction. The tag questions in English are formed according to the tense form, the affirmative or negative form of the verb, the person of the pronoun, the type of the verb etc. For example: "You went home, didn't you?", "You didn't go home, did you?", "She likes ice-cream, doesn't she?" Meanwhile, the tag question in Armenian is the same regardless of tense form used in

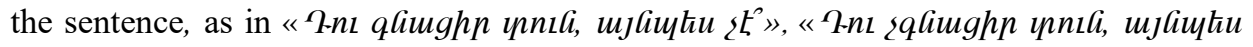

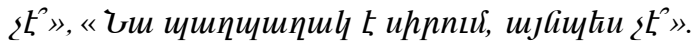

These types of systematic errors may be taken as evidence of learners' current transitional competence. In other words, it reflects the learners' attempts to make sense of the input in their own particular ways and to make an effort to organize the information provided by the language to which they are exposed (Smith 1994:24). As we can see, interlingual transfer is a significant source of error for all learners. The beginning stages of learning a second language are especially vulnerable to interlingual transfer from the native language. In these early stages, the native language is the only linguistic system upon which the learner can rely before the system of the second language becomes familiar. Accordingly, a wide range of strategies such as the control over the learning pace, the proportion of input and resulting uptake and most importantly, the provision of relevant corrective feedback should be taken into consideration. Also, the classification of Armenian native speakers' English learning errors into definite categories may create a favorable ground for modeling appropriate interference error treatment methods.

\section{Conclusion}

Our analysis enables us to conclude that learning a second language does entail proportionate transfer from the native language of the learners to the target language. Native language is the learners' prior linguistic system upon which they organize the new linguistic data. Every learner has an individual system-builder, he/she analyzes this input differently and produces different uptake. The transitional filter through which the input is processed generates numerous interference errors typical of an individual learner. The fact that learners make errors which can be observed, analyzed and classified in order to reveal the system operating within the learner led to significant research in error analysis. The classification of the native Armenian speakers' interference errors into definite categories may be a certain contribution to these studies 
in terms of modeling appropriate error treatment methods. Last but not least, errors made by learners need to be analyzed carefully as they may hold the key to the understanding the process of second language acquisition.

\section{References:}

1. Brown, H.D. (2007) Principles of Language Learning and Teaching. San Francisco: Longman.

2. Corder, S. (1967) The Significance of Learners' Errors. // International Review of Applied Linguistics, 5, 161-170

3. Corner S. (1971) Idiosyncratic Dialects and Error Analysis. // International Review of Applied Linguistics,9, pp. 147-159.

4. Larsen-Freeman, D. (1991) An Introduction to Second Language Acquisition Research. London and New York: Longman.

5. Prator, C. (1967) Hierarchy of Difficulty. / Unpublished classroom lecture, University of California, Los Angeles.

6. Selinker, L. (1972) International Review of Applied Linguistics in Language Teaching, 10 (1-4), pp. 209-232.

7. Smith, M.Sh. (1994) Second Language Learning. Theoretical Foundations. London and New York: Longman.

8. (2012) Interlanguage: The Nature, the Issues and the Pedagogical Implication. Available at: <http://www.academia.edu/2344295/Interlanguage_Study_of_SLA [Accessed May 2015].

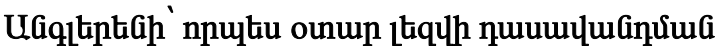

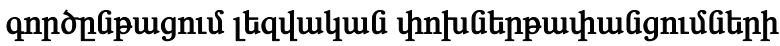

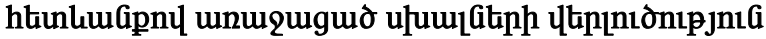

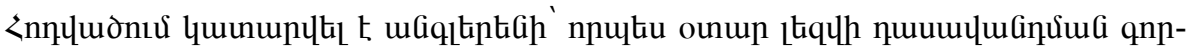

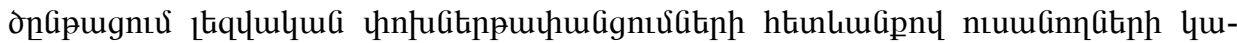

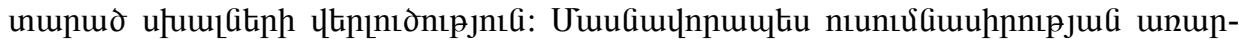

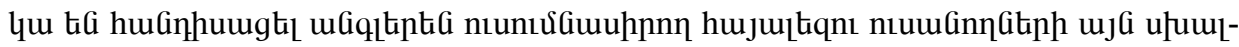

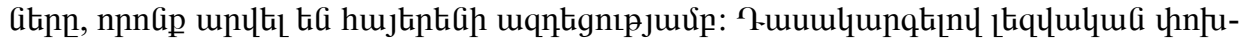

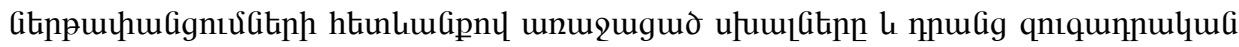

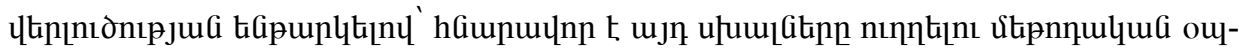

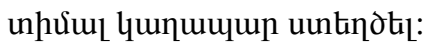




\section{Анализ ошибок, возникающих в процессе языковой интерференции в преподавании английского языка как иностранного}

В статье представлен анализ ошибок, совершаемых студентами вследствие языковой интерференции в процессе изучения английского языка как иностранного.

Предметом особого внимания выступает влияние армянского языка на возникновение ошибок у армяноговорящих студентов, изучающих английский язык. Актуальность статьи заключается в том, что посредством классификации и сопоставительного анализа ошибок, возникающих вследствие языковой интерференции, можно создать оптимальные модели, корректирующие эти ошибки. 